\title{
Correction to: New closed-loop insulin systems
}

\author{
Charlotte K. Boughton ${ }^{1}$ (D) $\cdot$ Roman Hovorka ${ }^{1}$ (D)
}

(C) The Author(s) 2021

\section{Correction to: Diabetologia https://doi.org/10.1007/s00125-021-05391-w}

This paper was published with Open Access. The copyright line has been updated to indicate that the authors retain copyright.

Open Access This article is licensed under a Creative Commons Attribution 4.0 International License, which permits use, sharing, adaptation, distribution and reproduction in any medium or format, as long as you give appropriate credit to the original author(s) and the source, provide a link to the Creative Commons licence, and indicate if changes were made. The images or other third party material in this article are included in the article's Creative Commons licence, unless indicated otherwise in a credit line to the material. If material is not included in the article's Creative Commons licence and your intended use is not permitted by statutory regulation or exceeds the permitted use, you will need to obtain permission directly from the copyright holder. To view a copy of this licence, visit http://creativecommons.org/licenses/by/4.0/.

Publisher's note Springer Nature remains neutral with regard to jurisdictional claims in published maps and institutional affiliations.

The online version of the original article can be found at https://doi.org/ 10.1007/s00125-021-05391-w

Roman Hovorka

rh347@cam.ac.uk

1 Wellcome Trust-Medical Research Council Institute of Metabolic

Science, University of Cambridge, Cambridge, UK 